\title{
Effect of Genotyps and Polyethylene Glycol on Immature Embryo Culture in Wheat

\author{
Rehab M. M. Habiba ${ }^{1}$; A. M. El-Adl' ${ }^{1}$ S. A. Abd El-Mageed ${ }^{2}$ and Kh. A. A. Gomaa ${ }^{1}$ \\ ${ }^{1}$ Dept. of Genetics, Fac. of Agric., Mansoura University, Egypt \\ ${ }^{2}$ Wheat Res. Dept., Field Crops Res. Inst., ARC, Egypt
}

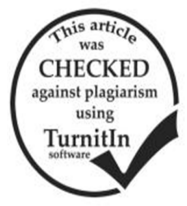

\section{ABSTRACT}

Seven wheat genotypes were used in this investigation to study the effect of genotypes, levels of polyethylene glycol (PEG) concentrations and their interaction on immature embryo induction, as well as, estimating heritability for in vitro traits. The genotypes were in vitro evaluated for immature embryos culture ability at four levels of PEG concentrations. Significant differences between genotypes were obtained for some traits at four PEG levels. Levels of mean squares were significant for some traits such as number of green point, plant length and number of tillers. Whereas, mean squares of interaction between genotypes $\times$ PEG levels was insignificant for all traits except number of tillers. The results demonstrated that the greatest percentages for green points and plant weight were recorded by the hybrid Sakha $93 \times$ Gemmiza 9 . In addition, Sakha $93 \times$ Sids 1 was the best genotype for root length and number of tillers. Whereas, the greatest value for number of plantlets was observed in Sakha 93 and sakha 94 . The addition of 10 g/1 PEG to MS nutrient medium and $1 \mathrm{mg} / \mathrm{l} \mathrm{NAA}$ and $0.5 \mathrm{mg} / \mathrm{l} \mathrm{Kinetin} \mathrm{in} \mathrm{regeneration} \mathrm{medium} \mathrm{could} \mathrm{be} \mathrm{the} \mathrm{best} \mathrm{concentration} \mathrm{for} \mathrm{immature} \mathrm{embryo}$ purpose in wheat. Furthermore, the genetic variations were highly positive for some traits such as number of green point at levels A and $\mathrm{B}$, number of plants at levels $\mathrm{A}, \mathrm{B}$ and $\mathrm{D}$, plant weight at level A, plant length at level C, root length at level A and number of tillers at levels A,B and D. The values of heritability were ranged between 53.66 to $90.48 \%$ for number of tillers at levels D and A, respectively. The results indicated that the genes controlled growing traits in wheat were highly affected by media composition.

Keywords: Wheat, immature embryo culture, polyethylene glycol.

\section{INTRODUCTION}

Wheat is one of the most important cereal crops in the world. There are several species of Triticum. These species fall into three distinct groups, such as Diploids, Tetraploids and Hexaploids with 14, 28, and 42 chromosomes, respectively, according to (Martin \& Leonard 1963).

In Egypt, 1.26 million hectares were planted with wheat in 2017 with average yielding 8.8 million tons. However, this is not enough for Egyptian population consumption, it is necessary decreasing the gap between the local production and the consumption. The improved cultivar is one of the main factors increases crop productivity.

The calli derived from immature embryo and immature inflorescences of Triticum have higher ability of differentiation and regeneration than those from other explant tissues (Bi and Wang 2008).

In plant cell cultures, water stress can occur by adding osmotic, such as polyethylene glycol, mannitol, sorbitol and sucrose. Polyethylene glycol is one of the most common methods that depends on the use of high molecular weight of osmotic substances (Rao and Jabeen 2013). These agents have no detrimental or toxic effects on the plant; they inhibit the plant's growth by reducing the water potential of the culture medium in a way similar to soil drying, so that cultured explants are unable to take up water (Bressan et al., 1981).

Several studies have been reported on the effect of polyethylene glycol (PEG) on callus induction and plant regeneration from explants of graminious species (Farshadfar \& Amiri 2016 and Kacem et al., 2017). In most of these studies, an optimal concentration of PEG for callus induction and growth was investigated which varied with the species.

Thus, this investigation aimed to study the effect of genotypes, levels of PEG concentrations and their interaction on immature embryo induction in whea, as well as, estimating heritability for in vitro traits.

\section{MATERIALS AND METHODS}

\section{Plant material}

Four bread wheat genotypes (Triticum aestivum L.), which were chosen according to their degree of drought tolerance to be used in this study. They are included Sakha 93 (Tolerant), Sids 1 (Tolerant), Sakha 94 (Sensitive ) and Gemmiza 9 (Sensitive), as well as, three crosses derived from these parents have been used as follows:

Cross $1=\quad($ Sakha 93 $\times$ Sids 1$) \quad$ Tolerant $x$ Tolerant Cross $2=($ Sakha $93 \times$ Gemmiza 9$)$ Tolerant $x$ Sensitive

Cross $3=($ Sakha $94 \times$ Gemmiza 9$)$ Sensitive $x$ Sensitive

All genotypes were supplied by Field Crops Research Institute, Agricultural Research Center, Giza, Egypt.

Embryo culture procedure

During winter season of 2016/2017, seeds of genotypes the studied varieties and crosses were cultivated at the Experimental Farm of Sids, Agricultural Research Station, Benysweif, Egypt. Young spikes were collected about 15 days post anthesis from each genotype. Immature caryopses were surface sterilized under sterile conditions by immersing them for one minute in $75 \%$ ethanol followed by immersion in $0.1 \%$ mercuric chloride solution with 2 drops of Tween 20 as a wetting agent for 20 minutes. Then, it was rinsed three times in sterile double distilled water. Immature embryos were excised from each grain aseptically and cultured with the scutellm side up on induction medium under sterile conditions. The induction medium used in this study was MS medium, which recommended by Murashige and Skoog (1962) containing $3 \%$. The $\mathrm{pH}$ was adjusted to 5.8 before autoclaving at $121{ }^{\circ} \mathrm{C}$ for 20 minutes. The cultures were incubated in darkness at $25^{\circ} \mathrm{C} \pm 2{ }^{\circ} \mathrm{C}$ for four weeks. The produced calli were transferred to regeneration medium with $1 \mathrm{mg} / \mathrm{l}$ NAA, $0.5 \mathrm{mg} / \mathrm{l}$ Kinetin and supplemented with four different concentrations of PEG as the following;
A: MS medium with 0 g/l PEG
B: MS medium with 10 g/l PEG
C: MS medium with 20 g/l PEG
C: MS medium with 30 g/l PEG 
The cultures were kept under 16 hour's illumination (fluorescent light) at $22^{\circ} \mathrm{C} \pm 2{ }^{\circ} \mathrm{C}$ for four weeks. The regenerable calli, which have green shoot primordial (G.P) were counted and transferred to the same regeneration medium at the same condition for shoot development to four weeks. When the regenerated plants were about $5-8 \mathrm{~cm}$ length and have normal roots and shoots, they were carefully pulled up from the containers and their roots were washed with tap water to remove the remained parts of medium. Then, the total number of plantlet (NP), plant weight (PW), plant length (PL), root length (RL) and number of tillers (NT) were recorded according to Habiba et al., (2013).

\section{Experimental design}

The experiments were designed as a complete randomized system for all genotypes used under four different levels of PEG. Sterilized specific MS medium autoclaved at $121^{\circ} \mathrm{C}, 1.5 \mathrm{Ib} / \mathrm{inch}^{2}$ for $20 \mathrm{~min}$ was distributed into culture Petri dishes $(12 \mathrm{~cm}$ inner diameter), each one contained $20 \mathrm{ml}$. One Petri dish containing 10 sterilized immature embryo is considered as one experimental unit according to Habiba et al., (2013).

\section{Statistical analysis}

All data were subjected to analysis of variance according to Steel and Torrie (1960). Subsequently partition of phenotypic variances to its components were done.

\section{RESULTS AND DISCUSSION}

\section{Analysis of variance}

As shown in Table 1, test of significance on the genotypes mean squares at the four levels of PEG indicated significant differences between genotypes for some in vitro traits with respect to the four PEG levels such as number of green point, plant weight and number of tillers at level A; number of green point and number of plants at level B, plant length at level $\mathrm{C}$ and number of plants at level D. In addition, the data of all genotypes obtained from PEG levels were set up in a combined analysis of variance and the obtained results are presented in Table 2. Genotypes mean squares were highly significant for all in vitro traits except plant weight and root length. These traits were: number of green point (GP), number of plants (NP), plant length (PL) and number of tillers (NT).

Table 1. Analysis of variance and genotypes mean squares at the four levels of PEG.

\begin{tabular}{lcccccccc}
\hline SOV & PEG levels & Df & GP & NP & PW (g) & PL (cm) & RL (cm) & NT \\
\hline \multirow{4}{*}{ Replicates } & A & & 0.110 & 0.057 & 0.023 & 6.588 & 0.355 & 0.011 \\
& B & 2 & 0.039 & 0.0004 & 0.285 & 68.260 & 1.646 & 1.622 \\
& C & & 0.271 & 0.119 & 1.162 & 5.609 & 0.640 & 0.195 \\
& D & & 0.155 & 0.001 & 0.005 & 4.028 & 0.163 & 0.021 \\
Genotypes & $\mathrm{A}$ & & $1.873^{* *}$ & 0.081 & $0.058^{*}$ & 5.539 & 0.614 & $0.188^{* *}$ \\
& $\mathrm{~B}$ & \multirow{2}{*}{6} & $1.887^{* *}$ & $0.065^{* *}$ & 0.143 & 40.090 & 0.454 & 1.959 \\
& $\mathrm{C}$ & & 0.514 & 0.110 & 1.470 & $8.896^{*}$ & 0.793 & 0.124 \\
& $\mathrm{D}$ & & 0.783 & $0.152^{* *}$ & 0.017 & 6.689 & 0.119 & 0.121 \\
Error & $\mathrm{A}$ & & 0.346 & 0.028 & 0.018 & 4.138 & 0.257 & 0.018 \\
& $\mathrm{~B}$ & \multirow{2}{*}{12} & 0.257 & 0.011 & 0.100 & 26.580 & 1.002 & 0.725 \\
& $\mathrm{C}$ & & 0.722 & 0.067 & 1.180 & 2.076 & 0.412 & 0.096 \\
& $\mathrm{D}$ & & 0.613 & 0.027 & 0.011 & 6.448 & 0.258 & 0.620 \\
\hline
\end{tabular}

Notes:

*** Significant at 0.05 and 0.01 levels of probability, respectively.

A: MS medium with 0 g/l PEG. B: MS medium with 10 g/l PEG.

D: MS medium with 30 g/l PEG. $\quad$ GP: number of green point

PL: plant length

RL: root length

C: MS medium with 20 g/l PEG.

NP: number of plants

PW: plant weigh

Table 2. Combined analysis of variance and genotypes mean squares, PEG levels and their interactions for all in vitro traits.

\begin{tabular}{lccccccc}
\hline SOV & df & GP & NP & PW (g) & PL(cm) & RL (cm) & NT \\
\hline Levels (L) & 3 & $1.900^{*}$ & 0.080 & 0.471 & $32.995^{*}$ & 0.856 & $0.932^{*}$ \\
Reps / L & 8 & 0.144 & 0.044 & 0.369 & $21.247^{*}$ & 0.701 \\
Genotypes(G) & 6 & $3.253^{* *}$ & $0.284^{* *}$ & 0.455 & $35.099^{* *}$ & 0.462 \\
G $\times$ L & 18 & 0.601 & 0.041 & 0.411 & 8.705 & 0.347 & $0.031^{* *}$ \\
Error & 48 & 0.485 & 0.033 & 0.327 & 9.809 & 0.482 & 0.225 \\
\hline
\end{tabular}

Notes:

*** Significant at 0.05 and 0.01 levels of probability, respectively.

GP: number of green point NP: number of plants $\quad$ PW: plant weigh

PL: plant length $\quad$ RL: root length $\quad$ NT: number of tillers

These findings indicate the presence of real differences among these genotypes. Therefore, the planned comparisons between genotypes and the partition of the phenotypic variance to its components are valid. Furthermore, levels mean squares were significant with respect to some in vitro traits such as; number of green point, plant length and number of tillers. Whereas, genotype $\times$ levels mean squares were insignificant for all traits except number of tillers. This indicated that all genotypes gave the same response at different PEG levels except number of tillers. In this respect, Khodadadi et al., (2014) found that the effects of genotype and also drought stress levels on the regeneration percentage appeared significant effects at $1 \%$ probability level. In addition, Kacem et al., (2017) observed significant differences among genotypes and PEG levels as well as their interactions for all traits. 
Mean performance of genotypes for in vitro traits

Means of all in vitro traits at four levels of PEG are presented in Table 3. The results showed that no specific variety was superior or inferior for all studied traits at all levels of PEG. However, at level A, the greatest means of plant weight, plant length and number of tillers were observed in sakha 94 with means of $0.516,8.260$ and 0.889 , respectively. Greatest means green point number and root length were observed in Sakha $93 \times$ Gemmiza 9 with means of 3.167 and 1.924 , respectively. The greatest mean value for number of plants was observed in sakha 93 with mean of 0.746 . The lowest mean values for plant weight, plant length and number of tillers were observed in sakha 93 with means of $0.136,4.130$ and 0.230 , respectively. The lowest mean value for number of green point was recorded in Sakha 94 with mean 1.000 and the lowest mean value for number of plants was observed in Sakha $93 \times$ Sids 1 with mean of 0.285 . Whereas, lowest mean value for root length was observed in Gemmiza $9 \times$ Sakha 94 with mean of 0.810 .

At level B, the greatest mean values for number of green point, root length and number of tillers were recorded in Sakha $93 \times$ Sids 1 with means of 3.583, 1.833 and 2.500 , respectively. The greatest mean values for plant weight and plant length were recorded in Gemmiza $9 \times$ Sakha 94 with means of 0.685 and 13.500 , respectively. Whereas, Sakha 93 gave the greatest value for number of plants with mean of 0.537 . On the other hand, the lowest mean value for number of green point was recorded in Sakha94 with mean of 1.250 , number of plants was recorded in Sakha $93 \times$ Sids 1 with mean of 0.118 , plant weight was recorded in Gemmiza9 with mean of 0.228 , plant length was recorded in Sakha $93 \times$ Gemmiza 9 with mean of 4.660, root length was recorded in Sids1 with mean of 0.863 and number of tillers was recorded in Sakha 93 with mean of 0.333 .

At level $\mathrm{C}$, the greatest mean values for plant weight and number of tillers were recorded in Sakha $93 \times$ Gemmiza 9 with means of 2.171 and 0.986 ; respectively. In addition, the greatest mean value for; plant length was recorded in Sakha $93 \times$ Sids 1 with mean of 8.833 , number of green point was recorded in Gemmiza $9 \times$ Sakha 94 with mean of 2.417. Whereas, Sakha 93 gave the greatest value for number of plants with mean of 0.738 , as well as, Gemmiza 9 gave the greatest value for root length with mean of 1.979. On the other hand, the lowest mean values for number of green point, plant weight, plant length, root length and number of tillers were recorded in Sakha 93 with means of $1.083,0.214,4.763,0.510$ and 0.400 respectively. While, the lowest mean value for number of plants was recorded in Gemmiza $9 \times$ Sakha 94 with mean of 0.255 .

At level D, the greatest mean values for number of green point and plant length were recorded in Sids1 with means of 2.500 and 7.670, respectively. The greatest mean value for; number of plants was recorded in Sakha 93 with mean of 0.889 , root length was recorded in Gemmiza9 with mean of 1.088 . Whereas, Sakha $93 \times$ Gemmiza 9 gave the greatest value for plant weight with mean of 0.326 , Sakha $93 \times$ Sids 1 gave the greatest value for number of tillers with mean of 0.796 . On the other hand, the lowest mean values for number of green point, plant length and root length were recorded in Sakha 93 with means of $1.083,4.370$ and 0.593 , respectively. The lowest mean values for plant weight and number of tillers were recorded in Gemmiza 9 with means of 0.167 and 0.278 , respectively. Whereas, Sids1 gave the lowest mean value for number of plants with mean of 0.230 .

Table 3. Mean performance of genotypes for all in vitro traits at different PEG levels.

\begin{tabular}{|c|c|c|c|c|c|c|c|c|c|c|c|c|}
\hline \multirow{2}{*}{ Genotypes } & \multicolumn{4}{|c|}{ Plant length $(\mathrm{cm})$} & \multicolumn{4}{|c|}{ Root length $(\mathrm{cm})$} & \multicolumn{4}{|c|}{ Number of tillers } \\
\hline & $\mathbf{A}$ & B & $\mathrm{C}$ & D & $\mathbf{A}$ & B & $\mathrm{C}$ & D & $\mathbf{A}$ & B & $\mathbf{C}$ & D \\
\hline$\overline{\text { Sids } 1}$ & $5.340^{\mathrm{a}}$ & $5.380^{\mathrm{a}}$ & $5.074^{\mathrm{b}}$ & $7.670^{\mathrm{a}}$ & $0.979^{\mathrm{ab}}$ & $0.863^{\mathrm{a}}$ & $0.815^{\mathrm{ab}}$ & $0.917^{\mathrm{a}}$ & $0.597^{\mathrm{b}}$ & $0.539^{b}$ & $0.407^{\mathrm{a}}$ & $0.583^{\mathrm{abc}}$ \\
\hline Sakha 93 & $4.130^{\mathrm{a}}$ & $5.920^{\mathrm{a}}$ & $4.763^{b}$ & $4.370^{\mathrm{a}}$ & $0.945^{\mathrm{ab}}$ & $0.917^{\mathrm{a}}$ & a $\quad 0.510^{b}$ & b $0.593^{\mathrm{a}}$ & ${ }^{\mathrm{a}} 0.230^{\mathrm{c}}$ & $0.333^{\mathrm{b}}$ & $0.400^{\mathrm{a}}$ & $0.319^{\mathrm{bc}}$ \\
\hline Sakha 94 & $8.260^{\mathrm{a}}$ & $10.940^{\mathrm{a}}$ & $8.398^{\mathrm{a}}$ & $7.440^{\mathrm{a}}$ & $1.593^{\mathrm{ab}}$ & $1.639^{\mathrm{a}}$ & a $0.880^{\mathrm{ab}}$ & ab $0.778^{\mathrm{a}}$ & $0.889^{\mathrm{a}}$ & $0.750^{\mathrm{b}}$ & $0.519^{\mathrm{a}}$ & $0.556^{\mathrm{abc}}$ \\
\hline Gemmiza 9 & $5.520^{\mathrm{a}}$ & $6.330^{\mathrm{a}}$ & $6.646^{\mathrm{ab}}$ & $4.370^{\mathrm{a}}$ & $0.981^{\mathrm{ab}}$ & $1.222^{\mathrm{a}}$ & a $\quad 1.979^{\mathrm{a}}$ & $7^{\mathrm{a}} 1.088^{\mathrm{a}}$ & $0.289^{\mathrm{c}}$ & $0.370^{\mathrm{b}}$ & $0.500^{\mathrm{a}}$ & $0.278^{\mathrm{c}}$ \\
\hline Sakha $93 \times$ Gemmiza 9 & $4.890^{\mathrm{a}}$ & $4.660^{\mathrm{a}}$ & $4.786^{\mathrm{b}}$ & $5.170^{\mathrm{a}}$ & $1.924^{\mathrm{a}}$ & $1.116^{\mathrm{a}}$ & a $1.653^{\mathrm{ab}}$ & ab $1.083^{\mathrm{a}}$ & ${ }^{\mathrm{a}} 0.639^{\mathrm{b}}$ & $0.664^{\mathrm{b}}$ & $0.986^{\mathrm{a}}$ & $0.750^{\mathrm{ab}}$ \\
\hline Sakha $93 \times$ Sids 1 & $6.830^{\mathrm{a}}$ & $12.170^{\mathrm{a}}$ & $8.833^{\mathrm{a}}$ & $6.700^{\mathrm{a}}$ & $1.731^{\mathrm{ab}}$ & $1.833^{\mathrm{a}}$ & a $1.333^{\mathrm{ab}}$ & ab $1.000^{\mathrm{a}}$ & ${ }^{\mathrm{a}} 0.734^{\mathrm{ab}}$ & $2.500^{\mathrm{a}}$ & $0.667^{\mathrm{a}}$ & $0.796^{\mathrm{a}}$ \\
\hline Gemmiza $9 \times$ Sakha 94 & $5.510^{\mathrm{a}}$ & $13.500^{\mathrm{a}}$ & $7.370^{\mathrm{ab}}$ & $4.420^{\mathrm{a}}$ & $0.810^{\mathrm{b}}$ & $1.667^{\mathrm{a}}$ & a $1.009^{\mathrm{ab}}$ & ab $0.667^{\mathrm{a}}$ & a $0.326^{\mathrm{c}}$ & $1.667^{\mathrm{ab}}$ & $0.528^{\mathrm{a}}$ & $0.667^{\mathrm{abc}}$ \\
\hline \multirow{2}{*}{ Genotypes } & \multicolumn{4}{|c|}{ Number of green point } & \multicolumn{4}{|c|}{ Number of plants } & \multicolumn{4}{|c|}{ Plant weight (g) } \\
\hline & $\overline{\mathbf{A}}$ & B & $\mathrm{C}$ & D & $\mathbf{A}$ & B & $\mathbf{C}$ & D & $\mathbf{A}$ & $\mathbf{B}$ & $\bar{C}$ & D \\
\hline Sids 1 & $2.083^{\mathrm{bc}}$ & $2.500^{\mathrm{b}}$ & $1.833^{\mathrm{a}}$ & $2.500^{\mathrm{a}}$ & $0.499^{\mathrm{ab}}$ & $0.395^{\mathrm{ab}} 0$ & $0.483^{\mathrm{a}}$ & $0.230^{b}$ & $0.295^{\mathrm{abc}}$ & $0.317^{\mathrm{a}}$ & $0.320^{\mathrm{a}}$ & $0.228^{\mathrm{a}}$ \\
\hline Sakha 93 & $1.583^{\mathrm{cd}}$ & $1.583^{\mathrm{c}}$ & $1.083^{\mathrm{a}}$ & $1.083^{\mathrm{a}}$ & $0.746^{\mathrm{a}}$ & $0.537^{\mathrm{a}} \quad 0$ & $0.738^{\mathrm{a}}$ & $0.889^{\mathrm{a}}$ & $0.136^{\mathrm{c}}$ & $0.240^{\mathrm{a}}$ & $0.214^{\mathrm{a}}$ & $0.174^{\mathrm{a}}$ \\
\hline Sakha 94 & $1.000^{\mathrm{d}}$ & $1.250^{\mathrm{c}}$ & $1.917^{\mathrm{a}}$ & $1.250^{\mathrm{a}}$ & $0.500^{\mathrm{ab}}$ & $0.389^{\mathrm{ab}} \quad 0$ & $0.304^{\mathrm{a}}$ & $0.450^{\mathrm{b}}$ & $0.516^{\mathrm{a}}$ & $0.680^{\mathrm{a}}$ & $0.339^{\mathrm{a}}$ & $0.335^{\mathrm{a}}$ \\
\hline Gemmiza 9 & $3.000^{\mathrm{ab}}$ & $2.500^{\mathrm{b}}$ & $2.000^{\mathrm{a}}$ & $2.083^{\mathrm{a}}$ & $0.329^{b}$ & $0.308^{\mathrm{bc}} 0$ & $0.328^{\mathrm{a}}$ & $0.450^{\mathrm{b}}$ & $0.235^{\mathrm{bc}}$ & $0.228^{\mathrm{a}}$ & $0.329^{\mathrm{a}}$ & $0.167^{\mathrm{a}}$ \\
\hline Sakha $93 \times$ Gemmiza 9 & $3.167^{\mathrm{a}}$ & $2.833^{\mathrm{ab}}$ & $2.167^{\mathrm{a}}$ & $2.083^{\mathrm{a}}$ & $0.289^{b}$ & $0.274^{\text {bcd }} 0$ & $0.622^{\mathrm{a}}$ & $0.255^{\mathrm{b}}$ & $0.337^{\mathrm{abc}}$ & $0.245^{\mathrm{a}}$ & $2.171^{\mathrm{a}}$ & $0.326^{\mathrm{a}}$ \\
\hline Sakha $93 \times$ Sids 1 & $2.750^{\mathrm{ab}}$ & $3.583^{\mathrm{a}}$ & $2.000^{\mathrm{a}}$ & $1.500^{\mathrm{a}}$ & $0.285^{\mathrm{b}}$ & $0.118^{\mathrm{d}} \quad 0$ & $0.261^{\mathrm{a}}$ & $0.384^{\mathrm{b}}$ & $0.476^{\mathrm{ab}}$ & $0.614^{\mathrm{a}}$ & $0.410^{\mathrm{a}}$ & $0.308^{\mathrm{a}}$ \\
\hline Gemmiza $9 \times$ Sakha 94 & $2.000^{\mathrm{bcd}}$ & $2.833^{\mathrm{ab}}$ & $2.417^{\mathrm{a}}$ & $1.917^{\mathrm{a}}$ & $0.474^{\mathrm{ab}}$ & $0.147^{\mathrm{cd}} 0$ & $0.255^{\mathrm{a}}$ & $0.290^{\mathrm{b}}$ & $0.216^{\mathrm{bc}}$ & $0.685^{\mathrm{a}}$ & $0.340^{\mathrm{a}}$ & $0.183^{\mathrm{a}}$ \\
\hline \multicolumn{13}{|l|}{ Notes: } \\
\hline Im with 20 & & $x^{2}+2$ & & & & & & & & & & \\
\hline
\end{tabular}

Since, genotypes gave different performance with different PEG levels as observed above for most of studied in vitro traits. So, the combined data over the four PEG levels could be more precise to present information concerning the behavior of these genotypes. Therefore, the average means of seven genotypes were determined from the combined data over PEG levels and the results are shown in Table 4. The results revealed that there are significant differences between paired of means in most traits. The results cleared that greatest values for green 
points and plant weight were recorded in Sakha $93 \times$ Gemmiza 9 with means 2.563 and 0.770 , respectively. In addition, Sakha $93 \times$ Sids 1 was the best genotype for root length and number of tillers. Whereas, the greatest value for number of plantlets was observed in Sakha 93 with mean of 0.728 , however sakha 94 was the best genotype for plant length with mean of 8.762. On the other hand, Sakha 93 appeared to be the wariest genotype for immature embryos culture purpose, which gave poorest response to this process for all studied traits except for number of plantlets among four levels of PEG. Abdelsamad et al.,
(2007) found that the greatest mean value for percentage of regeneration was recorded at 10\% PEG in Sakha 93 and DH-1 with means of 38.2 and $30.1 \%$, respectively, while the lowest mean values were recorded in DH-2 and Giza 168 with means of 32.4 and $12.5 \%$, respectively. At $20 \%$ PEG levels were significantly decreased in regeneration mean percentages in all genotypes. Sakha 93 gave the greatest value for plant regeneration with mean of $24.3 \%$. Helaly et al., (2103) found that Misr 1 showed the highest green point percentage at $6000 \mathrm{mg} / \mathrm{PEG}$, whereas Sakha 94 was the lowest in this respect.

Table 4. Mean performance of genotypes for all in vitro traits from the combined data of different levels of PEG.

\begin{tabular}{lcccccc}
\hline Genotypes & GP & NP & PW (g) & PL (cm) & RL (cm) & NT \\
\hline Sids 1 & $2.229^{\mathrm{a}}$ & $0.402^{\mathrm{b}}$ & $0.290^{\mathrm{ab}}$ & $5.865^{\mathrm{bc}}$ & $0.894^{\mathrm{ab}}$ & $0.532^{\mathrm{bcd}}$ \\
Sakha 93 & $1.333^{\mathrm{b}}$ & $0.728^{\mathrm{a}}$ & $0.191^{\mathrm{b}}$ & $4.796^{\mathrm{c}}$ & $0.741^{\mathrm{b}}$ & $0.321^{\mathrm{d}}$ \\
Sakha 94 & $1.354^{\mathrm{b}}$ & $0.411^{\mathrm{b}}$ & $0.467^{\mathrm{ab}}$ & $8.762^{\mathrm{a}}$ & $1.222^{\mathrm{ab}}$ & $0.678^{\mathrm{bcd}}$ \\
Gemmiza 9 & $2.396^{\mathrm{a}}$ & $0.354^{\mathrm{b}}$ & $0.240^{\mathrm{b}}$ & $5.718^{\mathrm{bc}}$ & $1.318^{\mathrm{ab}}$ & $0.359^{\mathrm{cd}}$ \\
Sakha 93 × Gemmiza 9 & $2.563^{\mathrm{a}}$ & $0.360^{\mathrm{b}}$ & $0.770^{\mathrm{a}}$ & $4.877^{\mathrm{c}}$ & $1.444^{\mathrm{a}}$ & $0.760^{\mathrm{bc}}$ \\
Sakha 93 × Sids 1 & $2.458^{\mathrm{a}}$ & $0.262^{\mathrm{b}}$ & $0.452^{\mathrm{ab}}$ & $8.633^{\mathrm{a}}$ & $1.475^{\mathrm{a}}$ & $1.174^{\mathrm{a}}$ \\
Gemmiza 9 $\times$ Sakha 94 & $2.292^{\mathrm{a}}$ & $0.291^{\mathrm{b}}$ & $0.356^{\mathrm{ab}}$ & $7.698^{\mathrm{ab}}$ & $1.038^{\mathrm{ab}}$ & $0.797^{\mathrm{a}}$ \\
\hline
\end{tabular}

Notes: Means followed by the same letter in the same column are not significantly different at 0.05 level of probability.

GP: number of green point NP: number of plants PW: plant weight

PL: plant length $\quad$ RL: root length $\quad$ NT: number of tillers

\section{Effect of PEG levels}

Owing to PEG effect as observed earlier, it could be more informative to average the performances of all genotypes over each level. Therefore, the means of PEG levels for all genotypes in vitro traits are presented in Table 5. The results appeared the greatest values at level B for all traits except number of plantlets and plant weight. These findings revealed that the addition of $10 \mathrm{~g} / \mathrm{l} \mathrm{PEG}$ to $\mathrm{MS}$ nutrient medium and $1 \mathrm{mg} / \mathrm{l} \mathrm{NAA}$ and $0.5 \mathrm{mg} / \mathrm{l} \mathrm{Kinetin} \mathrm{in}$ regeneration medium could be the best concentration for immature embryo culture purpose in wheat. This agreed with Jin Kang et al., (2003), who found that the low PEG level resulted in more green plants than either the control (zero PEG) or high PEG level, although no significant effect was found. Whereas, Kacem et al., (2017) found that increase in PEG levels reduced the number of calli. While, increase in PEG levels increased the time required for callus induction as well as frequency of embryogenic structures and number of plants.

Table 5. The PEG levels averaged overall genotypes for in vitro traits.

\begin{tabular}{lcccccc}
\hline Levels of PEG added to MS medium & GP & NP & PW (g) & PL (cm) & RL (cm) & NT \\
\hline A & $2.226^{\mathrm{ab}}$ & $0.446^{\mathrm{a}}$ & $0.316^{\mathrm{a}}$ & $5.783^{\mathrm{b}}$ & $1.280^{\mathrm{a}}$ & $0.529^{\mathrm{b}}$ \\
B & $2.440^{\mathrm{a}}$ & $0.310^{\mathrm{a}}$ & $0.430^{\mathrm{a}}$ & $8.414^{\mathrm{a}}$ & $1.322^{\mathrm{a}}$ & $0.975^{\mathrm{a}}$ \\
C & $1.917^{\mathrm{ab}}$ & $0.427^{\mathrm{a}}$ & $0.589^{\mathrm{a}}$ & $6.553^{\mathrm{ab}}$ & $1.168^{\mathrm{a}}$ & $0.572^{\mathrm{b}}$ \\
D & $1.774^{\mathrm{b}}$ & $0.421^{\mathrm{a}}$ & $0.246^{\mathrm{a}}$ & $5.734^{\mathrm{b}}$ & $0.875^{\mathrm{a}}$ & $0.564^{\mathrm{b}}$ \\
\hline
\end{tabular}

Notes: Means followed by the same letter in the same column are not significantly different at 0.05 level of probability.

$\begin{array}{lll}\text { GP: number of green point } \quad \text { NP: number of plants } \quad \text { PW: plant weight } & \end{array}$

$\begin{array}{lll}\text { PL: plant length } & \text { RL: root length } & \text { NT: number of tillers }\end{array}$

\section{Genetic parameters}

Genetic variation and heritability in broad $\left(\mathrm{H}_{\mathrm{b}}\right)$ sense were estimated within each PEG level for all traits as shown in Table 6 . The results revealed that the magnitude of genetic variation was positive for all in vitro traits at four levels of PEG except for number of green point at level C and root length at levels $\mathrm{B}$ and $\mathrm{D}$. The results showed that genetic variation was high for some traits at four levels of PEG concentration such as number of green point at levels $\mathrm{A}$ and $\mathrm{B}$, number of plants at levels $\mathrm{A}, \mathrm{B}$ and $\mathrm{D}$, plant weight at level $\mathrm{A}$, plant length at level $\mathrm{C}$, root length at level $\mathrm{A}$ and number of tillers at levels A,B and D. These results confirmed by the values of heritability, which ranged from 53.66 to $90.48 \%$ for number of tillers at levels $\mathrm{D}$ and $\mathrm{A}$, respectively.

The relative magnitudes of the parameters under investigation were estimated for all in vitro traits from the combined data over PEG levels and the obtained results are shown in Table 7 . The results revealed that the genetic variation were positively decreased in all traits except for number of green point and number of plants. In addition, genetic the values by interaction variations were positively decreased in all traits except for plant length and root length which give negative values. This finding explain the low values of heritability in these traits, as well as, the genes controling these traits are highly affected by media composition. Hamada et al., (2002) studied the diallel and cluster analysis for some quantitative characters in bread wheat and found that broad sense heritability was high for all traits. However, narrow sense heritability was high for most traits. Darwish and Ashoush (2003) tested two crosses and their six populations of bread wheat for grain yield, yield components and some growth attributes. Heritability in broad sense was high to moderate in magnitude, however, in narrow sense the values were high to low in its magnitude. Hendawy (2003) studied the genetic architecture of yield and its components and some other agronomic traits in bread wheat and reported that 
high heritability values in broad sense were recorded for most traits in the three crosses, although, high to moderate heritability values in narrow sense were also obtained for most traits in the three crosses. El-Borhamy (2004) studied performance of six genotypes and their $15 \mathrm{~F}_{1}$ hybrids of wheat under drought stress for plant height, grain yield and yield components. He found that heritability in narrow sense was low in most traits. Tammam (2005) studied six generation in wheat under different environmental conditions and reported that heritability in broad sense was high to moderate for studied traits under both treatments, however, heritability in narrow sense was low to moderate for the some traits under normal and drought treatments.
El-Hag (2006) estimated of genetic parameters for earliness and some agronomic characters in three crosses of bread wheat and obtained moderate to high broad and narrow sense heritability estimates were obtained for most traits in three crosses. Abd El-Rahman and hammad (2009) estimated of some genetic parameters for some agronomic characteristics in three crosses of bread wheat and found that heritability in broad and narrow sense were generally moderate to high in most traits in three crosses. Aboshosha and Hammad (2009) estimated of genetic parameters for yield and yield components as well as some agronomic characters in wheat and found that heritability in narrow sense was moderate to low in all traits.

Table 6. Estimates of relative magnitudes of different genetic parameters for in vitro traits at different levels of

\begin{tabular}{|c|c|c|c|c|c|c|c|c|c|c|c|c|}
\hline \multirow{2}{*}{$\begin{array}{l}\text { Genetic } \\
\text { Parameters }\end{array}$} & \multicolumn{4}{|c|}{ Number of green point } & \multicolumn{4}{|c|}{ Number of plants } & \multicolumn{4}{|c|}{ Plant weight (g) } \\
\hline & $\mathbf{A}$ & B & C & D & $\mathbf{A}$ & B & C & D & $\mathbf{A}$ & B & C & D \\
\hline$\overline{\sigma^{2} g}$ & 0.520 & 0.554 & -0.048 & 0.078 & 0.016 & 0.018 & 0.012 & 0.043 & 0.013 & 0.005 & 0.098 & 0.002 \\
\hline$\sigma^{2} \mathrm{e}$ & 0.104 & 0.075 & 0.219 & 0.183 & 0.011 & 0.003 & 0.025 & 0.008 & 0.006 & 0.042 & 0.392 & 0.003 \\
\hline$\sigma^{2} \mathrm{ph}$ & 0.624 & 0.629 & 0.171 & 0.261 & 0.027 & 0.021 & 0.037 & 0.051 & 0.019 & 0.047 & 0.490 & 0.005 \\
\hline $\mathrm{Hb} \%$ & 83.33 & 88.08 & 0.00 & 29.89 & 59.26 & 85.71 & 32.43 & 84.31 & 68.42 & 10.64 & 20.00 & 40.00 \\
\hline Genetic & \multicolumn{4}{|c|}{ Plant length $(\mathrm{cm})$} & \multicolumn{4}{|c|}{ Root length $(\mathrm{cm})$} & \multicolumn{4}{|c|}{ Number of tillers } \\
\hline Parameters & A & $\mathrm{B}$ & $\mathrm{C}$ & $\mathrm{D}$ & $\mathrm{A}$ & $\mathrm{B}$ & $\mathrm{C}$ & $\mathrm{D}$ & $\mathrm{A}$ & $\mathrm{B}$ & $\mathrm{C}$ & $\mathrm{D}$ \\
\hline$\overline{\sigma^{2} g}$ & 0.350 & 2.497 & 2.105 & 0.195 & 0.114 & -0.213 & 0.116 & -0.042 & 0.057 & 0.369 & 0.005 & 0.022 \\
\hline$\sigma^{2} \mathrm{e}$ & 1.496 & 10.867 & 0.860 & 2.034 & 0.090 & 0.365 & 0.148 & 0.082 & 0.006 & 0.284 & 0.037 & 0.019 \\
\hline$\sigma^{2} \mathrm{ph}$ & 1.846 & 13.364 & 2.965 & 2.229 & 0.204 & 0.152 & 0.264 & 0.040 & 0.063 & 0.653 & 0.042 & 0.041 \\
\hline $\mathrm{Hb} \%$ & 18.96 & 18.68 & 70.99 & 8.75 & 55.88 & 0.00 & 43.94 & 0.00 & 90.48 & 56.51 & 11.90 & 53.66 \\
\hline
\end{tabular}

Notes:

A: MS medium with $0 \mathrm{~g} / \mathrm{l}$ PEG D: MS medium with $30 \mathrm{~g} / \mathrm{l}$ PEG $\sigma^{2}$ ph: phenotypic variance

B: MS medium with
$\sigma^{2}$ g: genotypic variance
Hb\%: heritability in broad sense

Table 7. Estimates of relative magnitudes for different genetic parameters from the combined data over PEG levels.

\begin{tabular}{|c|c|c|c|c|c|c|}
\hline $\begin{array}{l}\text { Genetic } \\
\text { Parameters }\end{array}$ & GP & NP & $\begin{array}{l}\text { PW } \\
\text { (g) }\end{array}$ & $\begin{array}{l}\text { PL } \\
(\mathrm{cm})\end{array}$ & $\begin{array}{c}\text { RL } \\
\text { (cm) }\end{array}$ & NT \\
\hline$\sigma^{2} \mathrm{~g}$ & 0.221 & 0.020 & 0.004 & 2.200 & 0.049 & 0.048 \\
\hline$\sigma^{2} \mathrm{Gl}$ & 0.041 & 0.002 & 0.030 & -0.542 & -0.052 & 0.067 \\
\hline$\sigma^{2} \mathrm{e}$ & 0.159 & 0.012 & 0.107 & 3.443 & 0.168 & 0.084 \\
\hline$\sigma^{2} \mathrm{ph}$ & 0.391 & 0.032 & 0.118 & 5.508 & 0.204 & 0.149 \\
\hline $\mathrm{Hb} \%$ & 56.58 & 62.47 & 3.10 & 39.94 & 24.18 & 32.29 \\
\hline \multicolumn{7}{|l|}{$\begin{array}{l}\text { Notes: } \\
\text { GP: nu }\end{array}$} \\
\hline $\begin{array}{l}\text { GP: number o } \\
\text { PW: plant wei } \\
\text { RL: root lengt }\end{array}$ & & & $\begin{array}{l}\text { : plant } 1 \\
: \text { numb }\end{array}$ & $\begin{array}{l}\text { ngth } \\
r \text { of tiller }\end{array}$ & & \\
\hline
\end{tabular}

\section{REFERENCES}

Abd El-Rahman, E. and S. M. Hammad. (2009). Estimation of some genetic parameters for some agronomic characteristics in three crosses of bread wheat . J. Agric. Sci., Mansoura Univ., 34(2): 10911100

Abdelsamad, A; O. E. El-Sayed and Hayam, F. Ibrahim (2007). Development of drought tolerant double haploid wheat using biochemical genetic markers on In vitro culture. J. of Applied Sci. Research, 3 (11): 1589-1599.

Aboshosha, A.A.M. and S.M. Hammad (2009). Estimation of parameters for yield and yield components and some agronomic characters in two crosses of bread wheat (Triticum aestivum L.). J. Agric. Sci., Mansoura Univ., 34(5): 4293-4300.
Bi, R. and H. Wang (2008). Primary studies on tissue culture from mature embryos in diploid and tetraploid wheat. Front. Agric. Chin. 2: 262-265.

Bressan, R. A.; P. M. Hasegawa and A. K. Handa (1981). Resistance of cultured higher plant cells to polyethylene glycol-induced water stress. Plant Sci. Lett. 21: 23- 30.

Darwish, I.H.I. and H.A. Ashoush (2003). Hetersois, gene effects, heritability and genetic advance in bread wheat. Minufiya J. Agric. Res.28: 433-444.

EL-Borhamy, H.S. (2004). Genetic analysis of some drought and yield related characters in spring wheat varieties (Triticum aestivum L.). J. Agric. Sci., Mansoura Univ., 29 (7):3719-3729.

El-Hag, A.A. (2006). Estimation of genetic parameters for earliness and some agronomic characters in three crosses of bread wheat, (Triticum aestivum L.). J. Agric. Sci., Mansoura Univ., 31(7): 4271-4280.

Farshadfar, E. and R. Amiri (2016). In vitro application of integrated selection index for screening drought tolerant genotypes in common wheat. Acta agriculturae Slovenica. 107: 335 - 344.

Habiba, Rehab M. M.; M. M. Abd El- Maksoud and Kh. A. A. Gomaa (2013). Effect of genotyps and their interaction with 2,4 dichlorophenoxy acetic acid $(2,4-d)$ levels on wheats immature embryo culture response. Egypt. J. Genetic. Cytol., 42: 37-52.

Hamada, A. A.; N.A. Mohamed and F. Ashmawy (2002). Diallel and cluster analysis for some quantitative characters in bread wheat (Triticum aestivum L.). J. Agric. Sci., Mansoura Univ., 27: 5719-5734. 
Helaly, M. N.; Z. A. Mohamed; R. A. Fouda and Sally A. A. Arafa (2013). In vitro studies on bread wheat genotypes for drought tolerance using polyethylene glycol. J. Plant Production, Mansoura Univ., 4 (4): $605-620$.

Hendawy, H.I. (2003). Genetic architecture of yield and its components and some other agronomic traits in bread wheat. Minufiya J. Agric. Res., 28: 71-86.

Jin Kang, T.; M. Sik Yang and E. L. Deckard (2003). The effect of osmotic potential on anther culture in spring wheat (Triticum aestivum). Plant Cell, Tissue and Organ Culture 75: 35-40.

Kacem, N. S.; F. Delporte; Y. Muhovski; A. Djekoun and B. Watillon (2017). In vitro screening of durum wheat against water stress mediated through polyethylene glycol. Journal of Genetic Engineering and Biotechnology 15: 239-247.

Khodadadi, E.; L. fahmideh and B. Fakheri (2014). Evaluation of osmotic stress tolerance in wheat genotypes and solidarity of assessed traits using in vitro mature embryos culture. International Journal of Geology, Agriculture and Environmental Sciences 2: 1-7.
Martin, J. H. and W. H. Leonard (1963). Cereal Crops. The Macmillan Company New York. pp. 275-287.

Murashige, T. and F. Skoog (1962). A revised medium for rapid growth and bioassays with tobacco tissue culture. Physiol. Plant. 15: 473-497.

Rao, S. and F. T. Z. Jabeen (2013). In vitro selection and characterization of polyethylene glycol (PEG) tolerant callus lines and regeneration of plantlets from the selected callus lines in sugarcane (Saccharum officinarum L.). Physiol. Mol. Biol. Plants 19: 261-268.

Steel, R. G. and J. H. Torrie (1960). Principles and procedures of statistics. Mc-Graw Hill book Company, INC. New York.

Tammam A. M. (2005). Generation mean analysis in bread wheat under different environmental conditions. Minufiya J. Agric. Res. 30 (3): 937-956.

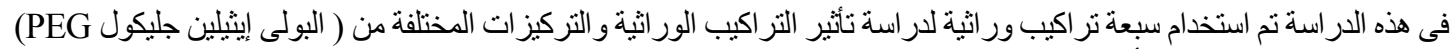



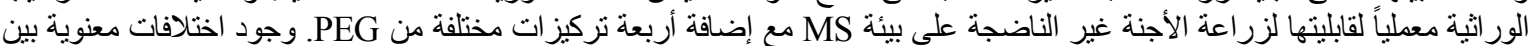

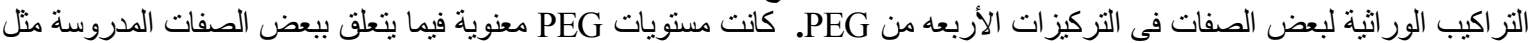



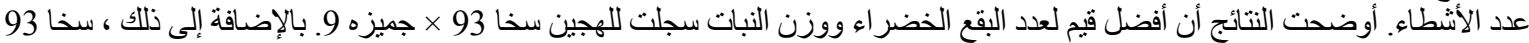

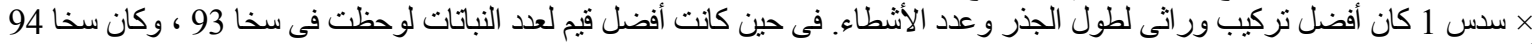

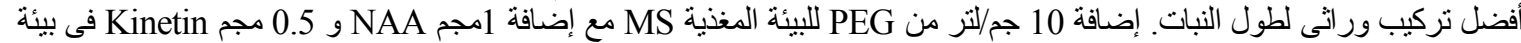
هegeneration

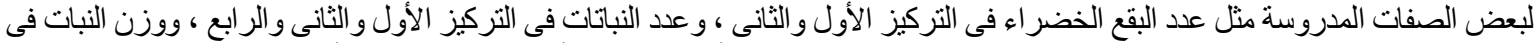



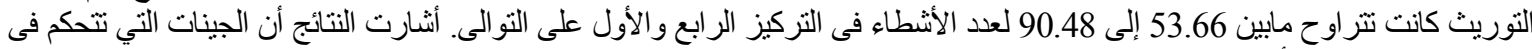
صفات النمو في القمح تأثرت بثندة بوانين اسطة مكونات البيئة. 